\title{
Regime dynamics of hydrochemical and toxicological parameters of the Irtysh River in Kazakhstan
}

\author{
Diana M BURLIBAYEVA ${ }^{1}$, Malik Zh BURLIBAYEV ${ }^{2 *}$, Christian OPP ${ }^{3}$, BAO Anming ${ }^{4}$ \\ ${ }^{1}$ Department of Water Resources and Land Reclamation, Kazakh National Agrarian University, Almaty 050010, Kazakhstan; \\ ${ }^{2}$ Kazakhstan Agency of Applied Ecology, Almaty 050012, Kazakhstan; \\ ${ }^{3}$ Department Hydrology \& Soil Science, Faculty of Geography, Philipps University, Marburg 35032, Germany; \\ ${ }^{4}$ Xinjiang Institute of Ecology and Geography, Chinese Academy of Sciences, Urumqi 830011, China
}

\begin{abstract}
Since the Irtysh River flows through the important economic, ecological and social territories of China, Kazakhstan and Russia, the water quality issues growingly draw the attention of the water authorities from these countries. Therefore, a detailed study of the hydrochemical regime and toxicological indicators in Kazakhstan was carried out for understanding the regime dynamics of water quality and its affect factors. The combined assessment of maximum permissible concentration (MPC) of chemical components and biotesting method were proposed and performed for the study area. The results clearly showed that the concentrations of single chemical component at different locations are mostly under MPC standard in a basin scale. However, the watershed surface runoff and tributary stream flow from mining industry areas had high concentration of heavy metals and had significant impact on the water quality near Ust-Kamenogorsk. Furthermore, even the stream water generally meet MPC standard, the results of biotesting method show the toxicity level of water sample is lethal for the test objects of phytoplankton and Daphnia. The survival rates of most water samples are lower than $46.7 \%$. Hereby, this study strongly suggests using combined water assessment methods to evaluate the water quality.
\end{abstract}

Keywords: hydrochemistry; biotesting method; Irtysh River; Kazakhstan

Citation: Diana M BURLIBAYEVA, Malik Zh BURLIBAYEV, Christian OPP, BAO Anming. 2016. Regime dynamics of hydrochemical and toxicological parameters of the Irtysh River in Kazakhstan. Journal of Arid Land, 8(4): 521-532. doi: $10.1007 / \mathrm{s} 40333-016-0083-\mathrm{y}$

The water quality issues draw a lot of attention (Boyd and Tucker, 2012; Khan et al., 2013) because of the matter of agriculture demand, economic development, public health and living qualities. Hydrochemical studies have become a part of environmental survey and research (Edet et al., 2013; Shah and Umar, 2015). The water quality management and trend forecast are the main concerns of environmental protection policy (Burlibayev et al., 2003, 2014; Bubonv et al., 2007; Burlibayev and Amirgaliyev, 2012).

The dynamic changes of chemical compositions, movement of nature water body, biogeochemical environment and anthropogenic influence make the water quality study a very complex (Zenin and Belousova, 1988) and difficult (Hem, 1985) subject. Even the chemical components in water body might be same, the reaction direction may be totally opposite because of the different external conditions. The complexity of natural water composition shows the same element can be found in different substances and valence states in nature (Stumm and Morgan, 2012). The external conditions may have the direct or indirect impacts from rocks, soils, living

\footnotetext{
*Corresponding author: Malik Zh BURLIBAYEV (E-mail: burlibayeva@yandex.kz)

Received 2015-06-02; revised 2015-10-12; accepted 2015-10-19

(C) Xinjiang Institute of Ecology and Geography, Chinese Academy of Sciences, Science Press and Springer-Verlag Berlin Heidelberg 2016
} 
organisms, human activities, climate, relief, water regime, vegetation, hydrogeological and hydrodynamic conditions, etc. (Hem, 1985). Therefore, it is essential to understand the dynamic changes of chemical and biological background in the regional scale.

Irtysh River has more than $30 \%$ of total national water resources in Kazakhstan. It is essential to the local agriculture and tap-water supply. There are many studies on water quality for different river basins of Kazakhstan recently (Turner and Rabalais, 1991; Shrestha and Kazama, 2007; Juahir et al., 2011; Osibanjo et al., 2011; Varol et al., 2012; Olmanson et al., 2013; Sun et al., 2015). Notably, within the severer water quality issue in Irtysh River basin due to climate and human activities, there have been very few studies on detailed investigation at basin scales. Since Irtysh River flows through the territories of three countries, China, Kazakhstan and Russia, water allocation and industrial activities make the dynamic changes of water quality more complex. Therefore, there is a great joint interests to explore the changes in hydrochemical regime and toxicological parameters for this region.

This study aims to reveal the hydrochemical regime at an annual scale for chemical component concentrations and spatially trace the major pollutants in Irtysh River, such as salt content, fiveday biochemical oxygen demand $\left(\mathrm{BOD}_{5}\right)$, phosphate, $\mathrm{Si}, \mathrm{Fe}, \mathrm{Cu}, \mathrm{Zn}, \mathrm{Ni}, \mathrm{Cr}^{6+}, \mathrm{Pb}, \mathrm{V}, \mathrm{Hg}, \mathrm{Cd}, \mathrm{Mn}$, As, volatile phenols, petroleum products, fluorides, oxidizability and nitrogen, which form a real picture of the pollution in this water body. Furthermore, toxicity assessment by using biotesting method was performed to investigate the reality of water quality in the view of biological methods. This research characterizes the dynamics of hydrochemical and toxicological parameters of the Irtysh River water and provides useful information for water management authorities.

\section{Study area}

The Irtysh River (Fig. 1) is the largest tributary of the Ob River. The Ob-Irtysh system forms a major drainage basin in Asia, encompassing most of Western Siberia and the Altay Mountains. The river basin lies in $47.1^{\circ}-53.8^{\circ} \mathrm{N}$ and $73.4^{\circ}-83.4^{\circ} \mathrm{E}$. The annual mean air temperature ranges from $-3.6^{\circ} \mathrm{C}$ in the southwestern plain areas and near large water bodies (lakes Teletskoye and Zaisan), to $-7^{\circ} \mathrm{C}$ in the mountainous areas. In most areas, the summer is warm with the highest temperature in July up to $22^{\circ} \mathrm{C}$ while the temperature in winter can drop to $-19^{\circ} \mathrm{C}$ in January. However, the

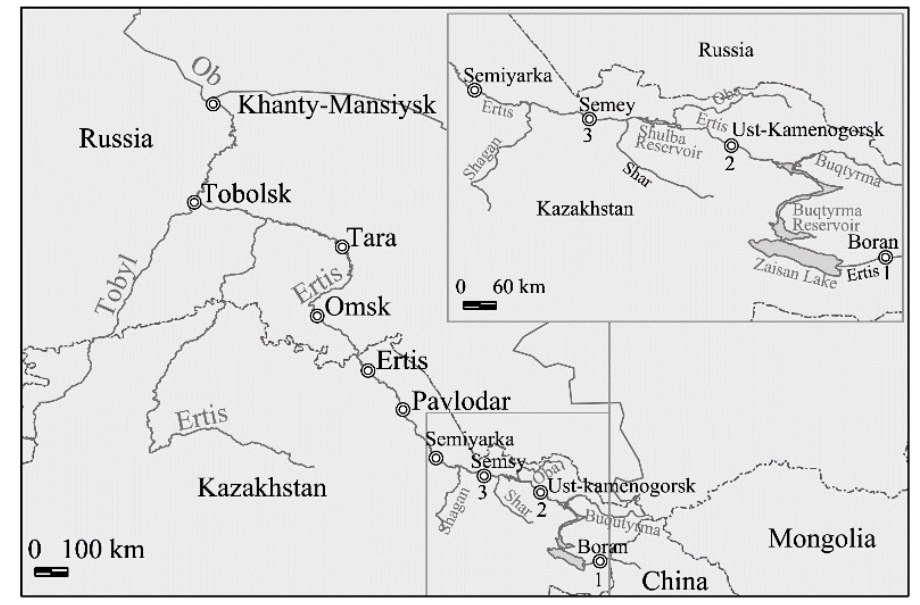

Fig. 1 The hydro-chemical survey points in the Irtysh River basin: Buran village at Black Irtysh River (1); 0.8 $\mathrm{km}$ down the hydroelectric dams near city of Ust-Kamenogorsk (2); $0.8 \mathrm{~km}$ downstream the Gorvodokanal discharge near city of Semey (3).

climate is generally much milder than that of neighbouring areas where the summer is cool and the winter is relatively warm (Vendrov and Kalinin, 1960). The precipitation evenly distributed in plain areas (e.g. 180-300 $\mathrm{mm}$ in the Zaisan hollow, Irtysh basin, and Kazakh hills) but significantly 
increase in mountain areas (e.g. 300-600 mm in Chingiz-Tau Mountains, Kalbinski ridge, and SaurTarbagatai Mountains) due to the strong effects of orography. The number of precipitation days are highly influenced by the elevation, and also increase from southwest to northeast in plain and foothill areas.

With total area of $1.6 \times 10^{6} \mathrm{~km}^{2}$, the Irtysh River basin has a well-developed water network system including the Irtysh River, lakes, artificial reservoirs and glaciers. The Irtysh River originates from the southwestern slopes of the Altay Mountains along the Mongolian-Chinese borders with the total length of 4,248 $\mathrm{km}$. In Kazakhstan territory, the average annual runoff of Irtysh River is around $3 \times 10^{8} \mathrm{~m}^{3}$. The Irtysh River is influenced by the snow melting and has frequent flooding events in spring (Burlibayev et al., 2006; INGEO, 2012). Currently the river basin is under the influence of huge anthropogenic load. Therefore, natural and anthropogenic factors together form the current hydrochemical regime of the basin.

\section{Methods and data collection}

\subsection{Methods}

As one basic standard of water quality assessment in the Republic of Kazakhstan, the maximum permissible concentration (MPC) is used in this study (Alekin, 1970; Zenin and Belousova, 1988; MZSR, 1991a, b; MEB, 1994). MPC is a standard that the amount of harmful substances in the environmental mediums (water, air and soil) practically do not affect the human health and do not cause negative effects on posterity under constant contact or under influence for a certain period of time. The following formula is used to determine the pollution level caused by a particular element. The ratio (Eq. 1) should be less than 1 if the particular element is under maximum permissible concentration.

$$
\frac{C_{i}}{M P C_{i}}<1,
$$

where $C_{i}$ is the concentration of chemical element $i$; $M P C_{i}$ is the maximum permissible concentration of chemical element $i$.

As a parallel method, biotesting (bioindication) is also applied in this work. Bioindication can be defined at the level of molecules, cells, organs (organ systems), organisms, populations or ecological community. The increasing level of wildlife organization can lead to complex and implicit relationship among natural factors, biological responses and anthropogenic factors in a study environment. Therefore, the most sensitive and simple organisms have been chosen for biotesing (Evgeniev, 1999). In this study, phytoplankton and Daphnia are selected as test objects. Survival rate of aquatic organisms is a good indicator in this process to determine the toxicity level of water no matter whether the contaminative materials were detected or not. Thus, the biotesting allows to determine the integrated toxicity level because the combination of all factors present in a sample of hazardous chemicals and their metabolites. Bio-indication allows ranking water by classes (normal, risky, crisis and disaster) or by functional behavior of the test objects (Crustacea: Daphnia, Algae: Chlorella, Fish: Guppy). The combination of chemical survey and biotesting can give a full picture of water quality concerned by local inhabitants and water management authorities.

\subsection{Data collection}

The monitoring network of the Republican State Enterprise (RSE) "Kazgidromet" provides integrated observations of hydrological parameters and hydrochemical regime. The data from this network are taken as a basis for this research since the monitoring network is permanently operated in the territory of Kazakhstan. However, the MPC approach was not able to present the true toxicant level and the additional field sampling for biotesting was carried out to reveal the realities of water quality in Irtysh River. Regarding the data completeness and representativeness, the period of 2010-2011 was selected for the study (RSE, 2007, 2008, 2009, 2010, 2011). The locations of 9 hydro-posts selected for MPC studies are listed in Table 1. For biotesting analysis, water samples 
were collected at other 9 hydro-posts located at the major tributaries of the Irtysh River (Table 1) in order to fully understand the dynamic changes of water quality in the spatial aspect.

Table 1 Hydro-posts selected for biotesting analysis

\begin{tabular}{cll}
\hline No. & Water object & Hydro-post \\
\hline 1 & Tihaya River & Ridder, a city $0.1 \mathrm{~km}$ downstream the zinc factory discharge \\
2 & Ulba River & $50 \mathrm{~m}$ upstream the mine waters discharge of Tishinsky mine \\
3 & Ulba River & $4.8 \mathrm{~km}$ downstream the mine waters discharge of Tishinsky mine \\
4 & Ulba River & Ust-Kamenogorsk, a city $1.45 \mathrm{~km}$ upstream the Ulba River mouth $(0.1 \mathrm{~km})$, at the highway bridge \\
5 & Ulba River & Ust-Kamenogorsk, a city $1.45 \mathrm{~km}$ upstream the Ulba River mouth $(0.9 \mathrm{~km})$, at the highway bridge \\
6 & Krasnoyarka River & Predgornoye village, $1.5 \mathrm{~km}$ upstream the household waste water discharge of Irtyshsky mine \\
7 & Krasnoyarka River & Predgornoye village, $0.5 \mathrm{~km}$ downstream Berezovsky mine, at the highway bridge \\
8 & Glubochanka River & Belousovka village, $5.5 \mathrm{~km}$ upstream the household fecal water discharge of Belousovka village \\
9 & Breksa River & Ridder, a city within the precincts of a town, 0.6 km upstream the Breksa Rver mouth \\
\hline
\end{tabular}

\section{Results and discussion}

The Irtysh River is one of the most important rivers for the local economy, ecology and society in Kazakhstan. Hereby, hydrochemical compositions of Irtysh River have to be assessed by long term and multiple indicators (Amirgaliyev, 1998; Burlibayev et al., 2006) to understand the dynamic movement, accumulation and dispelling of pollutants and the effects to the surrounding environment. The assessment was reviewed by the aspects of organic content, mineral contents, phosphorus and nitrogen.

\subsection{Assessment of hydrochemical and toxicological regime values of the transboundary tributary: the Black Irtysh River at Buran village}

\subsubsection{Organic content}

The data for 2010 and 2011 are presented in Fig. 2. The transit flow of the Irtysh River is characterized as low concentration of organic compounds with the value of dichromate oxidizability ranged from 4.0 to $11.0 \mathrm{mg} \mathrm{O}_{2} / \mathrm{L}$. Some fluctuation was observed during the flooding seasons (May and June). The value of $\mathrm{BOD}_{5}$ exceeded the MPC standard in $20 \%$ of samples analysed in 2010 and 2011 with a maximum of $4.03 \mathrm{mg} \mathrm{O} / \mathrm{L}$ observed in November to February next year and flooding season. Polluting substances of organic origin, such as volatile phenols, synthetic surfactants and fluorides are absent or lower than the MPC standard $(0.05 \mathrm{mg} / \mathrm{L})$ with seasonal variations of $0.02-0.04 \mathrm{mg} / \mathrm{L}$.

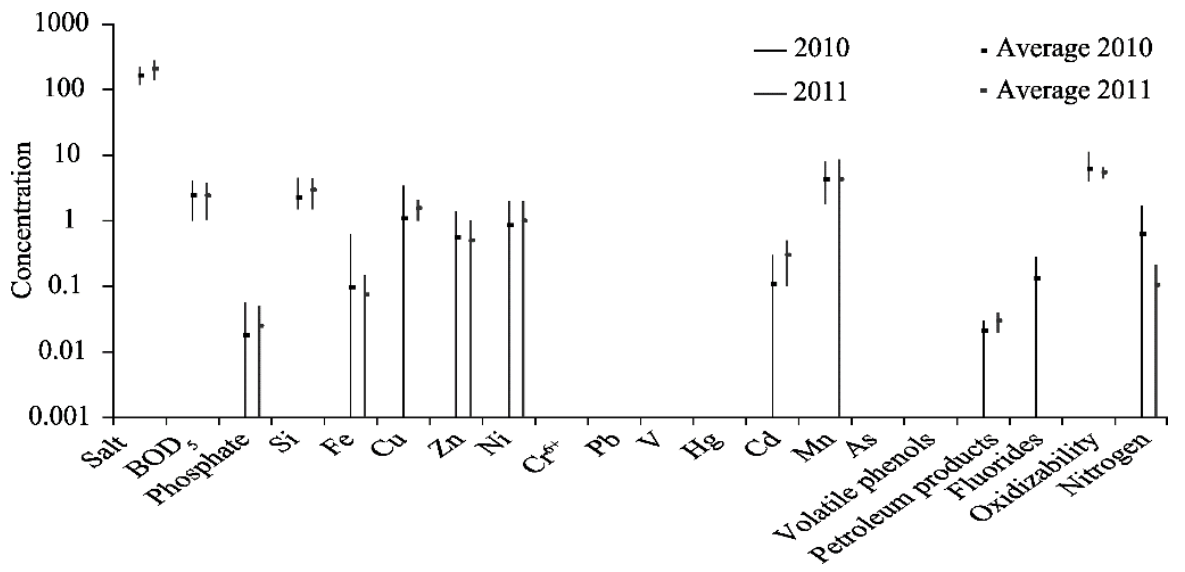

Fig. 2 Hydrochemical parameters of the Black Irtysh River at Buran village (The unit for salt content, Si, Fe, volatile phenols, petroleum products, fluorides and nitrogen is $\mathrm{mg} / \mathrm{L}$; the unit for $\mathrm{Cu}, \mathrm{Zn}, \mathrm{Ni}, \mathrm{Cr}^{6+}, \mathrm{Pb}, \mathrm{V}, \mathrm{Hg}, \mathrm{Cd}$, $\mathrm{Mn}$ and As is $\mu \mathrm{g} / \mathrm{L}$; the unit for oxidizability and $\mathrm{BOD}_{5}$ is $\mathrm{mg} \mathrm{O}_{2} / \mathrm{L}$.) 


\subsubsection{Phosphorus and nitrogen}

The total concentration of mineral forms of nitrogen shows high temporal variation, high concentration during the flooding season in 2010 and absent in other months. Similar data were obtained in 2011. Ammonium nitrogen was observed only in January and June, other forms of nitrogen were basically absent from January to August. Similar with nitrogen, the biogenic compounds of phosphorus and silicium were detected at low flow period (January and February) and flooding season with the concentrations below the MPC standard.

\subsubsection{Mineral contents}

According to data obtained in 2010 and 2011, a number of metals in transboundary flow were not detected (chromium, lead, vanadium, mercury, beryllium and arsenic) or considered as lower than MPC standard (zinc, nickel, cadmium and manganese). The river water has low salt content, mainly hydrocarbonate-calcium, with values from 116 to $277 \mathrm{mg} / \mathrm{L}$. Intra-annual distribution of metals is generally stable or slightly increasing in winter or flood season. Average annual concentration of iron was $0.097 \mathrm{mg} / \mathrm{L}$, lower than the MPC standard. Maximum concentrations were $0.120-0.620$ $\mathrm{mg} / \mathrm{L}$ in water samples collected in April to June 2010. In 2011 the content of this element sharply decreased with only $0.15 \mathrm{mg} / \mathrm{L}$ in April and $0.10 \mathrm{mg} / \mathrm{L}$ in May. Thus, the heavy metal content the flow is estimated as regulatory clean, with the exception of copper during the flooding season in 2010.

Therefore, transboundary runoff of the Irtysh River was not characterized by significant pollution. The river water meets the regulatory requirements of concentration and dynamics of hydrochemical and toxicological parameters for fisheries. Exceeded MPC standard level of total iron observed in some periods will not lead to noticeable deterioration of river water quality.

\subsection{Evaluation of hydrochemical and toxicological parameter changes along Bukhtarma Reservoir}

Monitoring for Bukhtama Reservoir are carried out at the Kuigan village and Bukhtarma settlement under the RSE "Kazgidromet" network. Since the Black Irtysh River joins Zaisan Lake before Bukhtarma reservoir, the current water quality can be considered as continuous evolution from the its boundary conditions, Lake Zaisan and upper Black Irtysh River. Hydrochemical regime and toxicological indicators of water quality are highly consistent between two survey sites at Kuigan village and Bukhtarma settlement. Therefore, the general trend and distinguish aspects are listed in below.

\subsubsection{Mineral contents}

Since the copper and total iron exceeded MPC standard at Buran, the concentrations of copper and total iron are still above MPC which copper reach 10MPC (10 times of MPC standard) in 83\% samples with the lowest concentration of 1 time of MPC. Furthermore, the concentration of silicon exceeded MPC in 50\% of the samples from the water reservoir near Kuigan village. The values of other hydrochemical ingredients were below the standard levels. Concentrations of nickel and cadmium vary strangely in the water reservoir. For example, nickel was not detected in water sample in June, but in August it was observed at a high level up to $2.80 \mu \mathrm{g} / \mathrm{L}$. Cadmium was not detected in June and August water samples but its increased concentration was recorded in July. Similar pattern was also observed for manganese in the summer: maximum concentrations recorded in June but absent in July. Salt content ranged from 180 to $203 \mathrm{mg} / \mathrm{L}$ which reflects the calciumhydrocarbonate class by its ionic composition with a characteristic of low-mineralized water. Chromium (6+), vanadium, mercury and arsenic were not observed in all water samples. The concentrations of Zinc, Cadmium, Nickel, and Manganese were significantly lower than MPC standard. The reservoir water was low-mineralized within $105-172 \mathrm{mg} / \mathrm{L}$; it belongs to calciumhydrocarbonate class by its ionic composition. The concentration of fluoride was low and ranges from 0.150 to $0.250 \mathrm{mg} / \mathrm{L}$.

\subsubsection{Organic contents}

The value of dichromate oxidizability was very low from 8.2 to $12.5 \mathrm{mg} \mathrm{O}_{2} / \mathrm{L}$ and $\mathrm{BOD}_{5}$ was from 1.0 to $1.7 \mathrm{mg} \mathrm{O} / 2$ while volatile phenols were detected only in July and August with a value of 
$0.001 \mathrm{mg} / \mathrm{L}$. The water near Kuigan village does not contain organic contaminants, such as oil hydrocarbons. $\mathrm{BOD}_{5}$ values (organic contaminant compounds) were within $1.110-2.730 \mathrm{mg} \mathrm{O} / \mathrm{L}$ which were below MPC standard. The average value of dichromate oxidizability during vegetative period is $4.4 \mathrm{mg} \mathrm{O}_{2} / \mathrm{L}$ while the maximum is $16.4 \mathrm{mg} \mathrm{O}_{2} / \mathrm{L}$. Volatile phenols and petroleum products were detected in water only in June with the values of 0.001 and $0.020 \mathrm{mg} / \mathrm{L}$, respectively, while they were not found in the rest months. This data indicates there is no sign of organic origin contaminants in the reservoir water.

Based on the above material, it can be noted that Bukhtarma reservoir water in the area of Kuigan village and Bukhtarma settlement is not severely contaminated. Minor exceedance of iron and copper are not dangerous for water use for domestic purposes and do not reduce the water quality for the habitat of aquatic organisms. Bukhtarma River, Narym River, and others tributary of the reservoir have no significant polluting effects on the reservoir area at hydro-post of Bukhtarma settlement.

A wide variety of heavy metals are not detected in water, the slight excess of iron and copper above MPC standard does not reduce the quality of water. Rivers Kurshim and Bukon flowing into the reservoir (above Kuigan village) do not have negative impacts on the water quality of the reservoir.

\subsection{Hydrochemical and toxicological indicators of the Irtysh River in the area of Ust- Kamenogorsk}

In the area of Ust-Kamenogorsk, the water quality monitoring of the Irtysh River is performed from the upper stream to the downstream at three sites of $0.5 \mathrm{~km}$ down the Titanium Magnesium Plant (TMP) discharge in 2010, $0.8 \mathrm{~km}$ down the hydroelectric dams (DHD) in 2010 and 2011, and 3.2 $\mathrm{km}$ down the Ulba River mouth (URM) from January to August in 2011. Observational data at these sites show the similarity of the hydrochemical regime and toxicological parameters (Fig. 3).

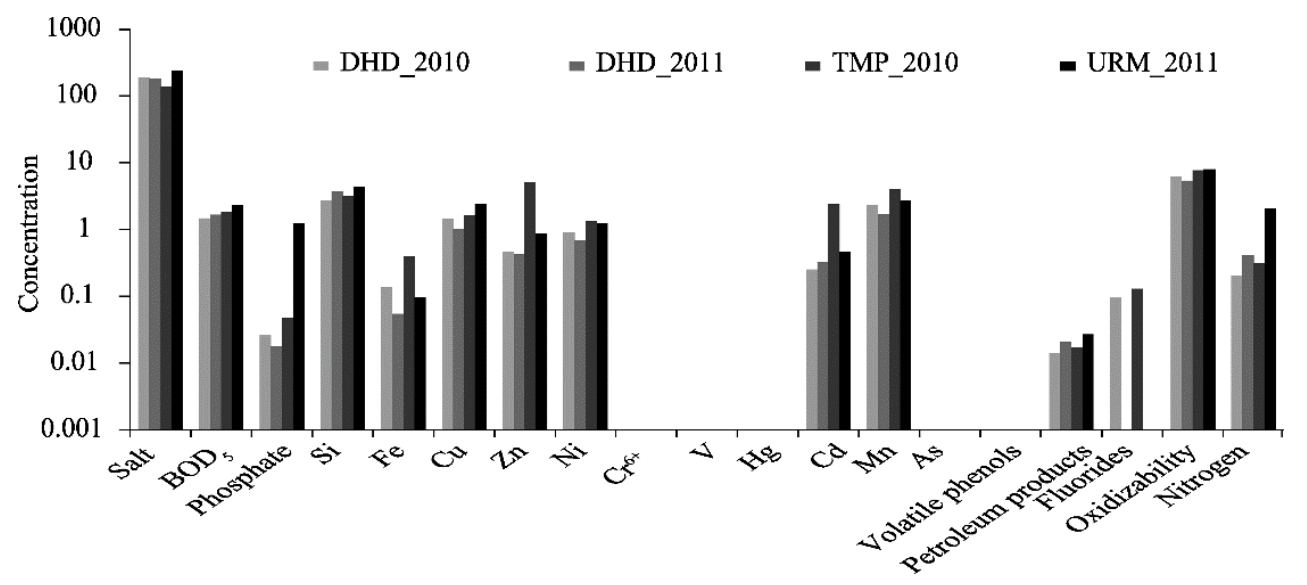

Fig. 3 Mean annual concentrations of hydrochemical and toxicological indicators of the Irtysh River area in UstKamenogorsk (The unit for salt content, $\mathrm{Si}$, Fe, volatile phenols, petroleum products, fluorides and nitrogen is $\mathrm{mg} / \mathrm{L}$; the unit for $\mathrm{Cu}, \mathrm{Zn}, \mathrm{Ni}, \mathrm{Cr}^{6+}, \mathrm{V}, \mathrm{Hg}, \mathrm{Cd}, \mathrm{Mn}$ and $\mathrm{As}$ is $\mu \mathrm{g} / \mathrm{L}$; the unit for oxidizability and $\mathrm{BOD}_{5}$ is $\mathrm{mg} \mathrm{O}_{2} / \mathrm{L}$.)

\subsubsection{Mineral contents}

Unlike the upper stream water body, the total iron at DHD only slightly exceeded the MPC standard in May 2010 during the flooding season. Maximum concentrations of copper were observed with $5.1 \mathrm{MPC}$ in 2010 and $1.6 \mathrm{MPC}$ in 2011 , although varies from time to time. Rest elements were recorded below MPC.

Copper concentration at URM varied in the range of 0.5-1.9MPC, occasionally reached 9.7MPC. Rest elements were also observed as below MPC.

The total iron content at TMP skyrockets up to 6-8MPC while copper concentration was relatively lower than that in the upper stream and varied from 1.3 to $3.0 \mathrm{MPC}$, the copper concentration even was not detected in September and December. High content of zinc (1.1- 
2.0MPC) was detected in January and February. The cadmium content was 1.6MPC in January. The water of this region has low salt content on average $139 \mathrm{mg} / \mathrm{L}$. Since the survey location is at the downstream of TMP discharge, it is expected to detect the presence of manganese. The concentrations of manganese are observed with the value of $1.9-7.5 \mu \mathrm{g} / \mathrm{L}$ which is below MPC standard. The trace of nickel was found in low concentrations occasionally. Some metals as chromium (6+), vanadium, mercury, arsenic were not found in the water. The water quality at TMP is considered as slightly polluted by minerals.

\subsubsection{Phosphorus and nitrogen}

Ammonia nitrogen at DHD slightly exceeded MPC standard in June 2010; other compounds of nitrogen group, phosphorus and silicon were found below MPC standard both in 2010 and 2011. The level of salt content in the river was low throughout the observation period with the value of $181-187 \mathrm{mg} / \mathrm{L}$.

Ammonium nitrogen at URM incredibly increased to 2.6 and 6.5MPC in February and June 2011 while phosphate concentration reached to 1.49 and $4.21 \mathrm{mg} / \mathrm{L}$ in June and August 2011, respectively. The anomalous concentrations of phosphates and ammonia reveal that there is unnatural phenomena happened between DHD and URM.

On the contrary, the concentration of phosphorus at TMP was low, from 0.011 to $0.154 \mathrm{mg} / \mathrm{L}$, and the maximum value was found in April. The exceedance of ammonium and nitrite nitrogen were observed in April to June 2010, mainly in the flooding season. Fluoride content was low and the maximum level $(3.8 \mathrm{mg} / \mathrm{L})$ was observed during the flooding season.

\subsubsection{Organic content}

The content of organic substances was characterized by low values around DHD for 2010 and 2011. Dichromate oxidizability was in the range of 5.350-6.167 $\mathrm{mg} \mathrm{O}_{2} / \mathrm{L}$, while $\mathrm{BOD}_{5}$ was from 1.469 and $1.658 \mathrm{mg} \mathrm{O}_{2} / \mathrm{L}$ respectively. Petroleum products were contained in water in low concentrations around $0.02-0.03 \mathrm{mg} / \mathrm{L}$ and not found in $30 \%-35 \%$ of samples.

The content of organic compounds at URM was similar with at DHM, the average $\mathrm{BOD}_{5}$ value was $2.3 \mathrm{mg} \mathrm{O}_{2} / \mathrm{L}$, water oxidizability was $7.9 \mathrm{mg} \mathrm{O}_{2} / \mathrm{L}$.

A minor content of organic substance at TMP was found during survey period. Dichromate oxidizability was in the range of 4.0-9.8 $\mathrm{mg} \mathrm{O}_{2} / \mathrm{L}$, only reached $20 \mathrm{mg} \mathrm{O}_{2} / \mathrm{L}$ in April. The average value of $\mathrm{BOD}_{5}$ was $1.8 \mathrm{mg} \mathrm{O} / \mathrm{L}$ and reach its maximum value of $3 \mathrm{mg} \mathrm{O} / 2$ in March. Volatile phenols were not detected.

\subsection{Water quality indicators of the Irtysh River in Ust-Kamenogorsk}

The water quality patterns near Predgornoye village in 2010 and 2011 are influenced by the upper stream city of Ust-Kamenogorsk (Fig. 4).

\subsubsection{Mineral contents}

Total iron content among heavy metals group exceeded the standard level in 2010 by $85 \%$ of the analyzed samples, while the similar excess was recorded by $40 \%$ of the samples in 2011 . Salt content was low with the values of $184-282 \mathrm{mg} / \mathrm{L}$ in 2010 and 186-204 mg/L in 2011.

Manganese was one of the major elements that exceeded maximum permissible concentration in water at this point. The highest content of manganese reached $12.0-13.0 \mu \mathrm{g} / \mathrm{L}(1.2-1.3 \mathrm{MPC})$ in January, March and May in 2010, but manganese strangely appeared below MPC standard in the remaining period of 2010 and throughout 2011.

Copper also reached 1.0 to 5.2 times of MPC standard from in $75 \%$ of samples both in 2010 and 2011 with the maximum concentration of $4.0-5.2 \mu \mathrm{g} / \mathrm{L}$ in March and May. The reason is the ablation from the river basin surface and some tributaries by melting water in spring, as well as by the storm runoff from the territory of large settlements and industrial enterprises.

While zinc exceeded the MPC standard by 1.6-9.6 times by $42 \%$ of samples in 2010 and 2011, its concentration was in the range of $1.0-1.9 \mu \mathrm{g} / \mathrm{L}$, i.e. the $0.1-0.2 \mathrm{MPC}$. However, zinc was not found in January and August. The highest zinc content was observed in the range of 60.0-96.0 $\mu \mathrm{g} / \mathrm{L}$ in 2010, i.e. 6.0-9.6MPC were observed in February, May and October. Consequently, the growth of its concentration was caused by anthropogenic pollution due to the associated ores. 
Fluorides were detected only in 2010 at concentrations up to $0.310 \mathrm{mg} / \mathrm{L}$. They were not found in May and October 2010 and for the last 5 months of 2011. Nickel and cadmium were detected in the water at this hydro-post with concentrations below MPC standard. Other elements like chromium (6+), beryllium, vanadium, mercury and arsenic were not found in the water here in 2010 and 2011.

\subsubsection{Phosphorus and nitrogen}

The minor exceedance of ammonium nitrogen and nitrite nitrogen were observed in 2010 and 2011 in the water at this hydro-post during the flooding seasons. $\mathrm{BOD}_{5}$ of $4.36 \mathrm{mg} \mathrm{O}_{2} / \mathrm{L}$ also has slight exceedance during the flooding seasons. Phosphates and silicon of biogenic compounds were detected in water in low concentrations. Phosphates were not detected in June and October 2010, and August 2011 which were obviously due to the consumption by aquatic vegetation.

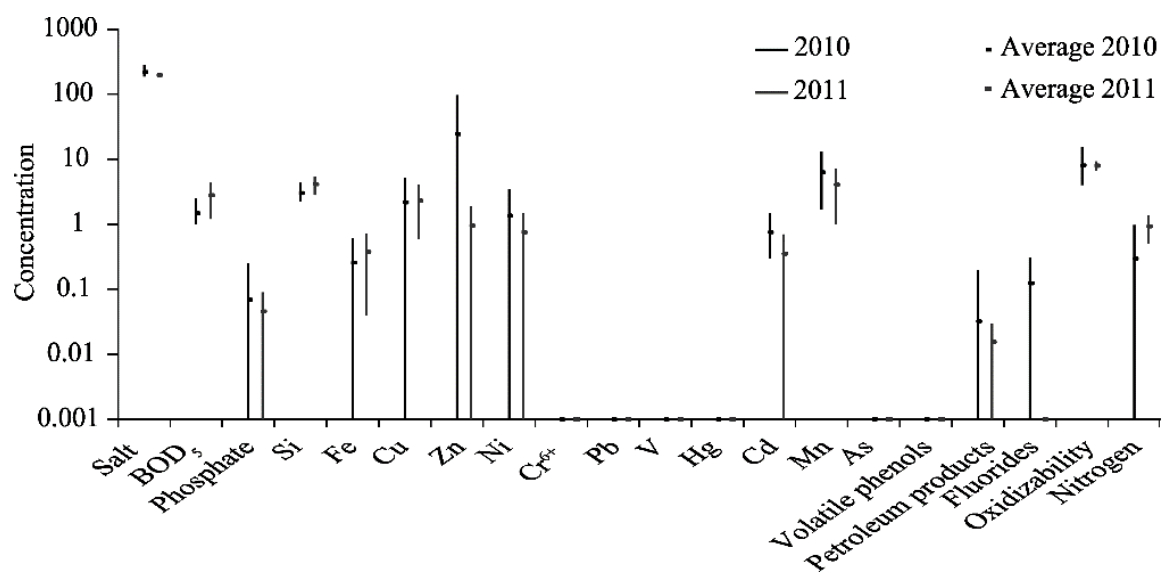

Fig. 4 Hydrochemical parameters at the Irtysh River downstream in Ust-Kamenogorsk (The unit for salt content, $\mathrm{Si}$, Fe, volatile phenols, petroleum products, fluorides and nitrogen is $\mathrm{mg} / \mathrm{L}$; the unit for $\mathrm{Cu}, \mathrm{Zn}, \mathrm{Ni}, \mathrm{Cr}^{6+}, \mathrm{Pb}, \mathrm{V}, \mathrm{Hg}$, $\mathrm{Cd}, \mathrm{Mn}$ and $\mathrm{As}$ is $\mu \mathrm{g} / \mathrm{L}$; the unit for oxidizability and $\mathrm{BOD}_{5}$ is $\mathrm{mg} \mathrm{O}_{2} / \mathrm{L}$.)

\subsubsection{Organic content}

$\mathrm{BOD}_{5}$ of $4.36 \mathrm{mg} \mathrm{O}_{2} / \mathrm{L}$ slightly exceeded MPC standard during the study period. Volatile phenols were not found in 2010 and 2011. Petroleum products were found in low quantities of $0.02 \mathrm{mg} / \mathrm{L}$ and at MPC standard level of $0.05 \mathrm{mg} / \mathrm{L}$. Furthermore, they were not detected in January and December 2010, and in March and August 2011 as well. Values of dichromate oxidizability were also low to $15.0 \mathrm{mg} \mathrm{O}_{2} / \mathrm{L}$ in 2010, and $9.2 \mathrm{mg} \mathrm{O}_{2} / \mathrm{L}$ in 2011 (Fig. 4).

Thus, increased concentrations of zinc, copper and manganese represent a hazard to water quality at this hydro-post by considering their exceedance of regulatory levels of MPC standard. The main reason for that, as mentioned above, is anthropogenic pollution of the river, particularly the confluence of the Krasnoyarka River into the Irtysh River, $1 \mathrm{~km}$ upstream the hydro-post, where water was contaminated with above-mentioned heavy metals. According to the report from the Republican State Enterprise "Kazgidromet" of the Ministry of Environmental Protection (RES, 2010, 2011), severe pollutants were observed at the $0.5 \mathrm{~km}$ downstream of Berezovsky mine discharge in Krasnoyarka River (near Predgornoye village) where copper concentration reached $42.0 \mu \mathrm{g} / \mathrm{L}$ in 2010 and $51.0 \mu \mathrm{g} / \mathrm{L}$ in 2011 , which is equivalent to 37 and $51 \mathrm{MPC}$; zinc content pops up to $2,824 \mu \mathrm{g} / \mathrm{L}$ (282MPC) in 2010 and $2,148 \mu \mathrm{g} / \mathrm{L}(215 \mathrm{MPC})$ in 2011 ; manganese concentration skyrockets to $194 \mu \mathrm{g} / \mathrm{L}$ in 2010 and $196 \mu \mathrm{g} / \mathrm{L}$ in 2011 (19.6MPC). Such contamination is a significant factor which impacted toxicological status of the area including not only the Krasnoyarka River but also the Irtysh River.

\subsection{Hydrochemical and toxicological indicators of the Irtysh River in Semey (Semipalatinsk)}

After the heavy contamination was observed from the upper stream of Semey where hydro-post is located $0.8 \mathrm{~km}$ downstream the Gorvodokanal discharge. It is meaningful to monitoring the effects 
of the corresponding hydrochemical elements for their downstream. Fortunately, the impacts from water quality indicators mentioned above it are not significant. Five hydrochemical indicators, $\mathrm{BOD}_{5}$, ammonium nitrogen, total iron, copper and petroleum products, slightly exceeded the MPC standard level in 2010. The exceedance of $\mathrm{BOD}_{5}$ appeared only in January 2010 and March 2011, and ammonium nitrogen was detected in May 2010 and 2011. Total iron content was slightly higher than the MPC standard level during the flooding season. Petroleum products was only observed in April 2010 with 1.1MPC.

\subsubsection{Mineral contents}

Copper concentration was in the range of $0.89-5.20 \mu \mathrm{g} / \mathrm{L}$ in 2010 and from 0.90 to $2.30 \mu \mathrm{g} / \mathrm{L}$ in 2011 with a maximum content of 5.2MPC. Low concentrations of zinc were detected with $2.7 \mu \mathrm{g} / \mathrm{L}$ in 2010 and $1.4 \mu \mathrm{g} / \mathrm{L}$ in 2011, comparing with MPC standard of $10 \mu \mathrm{g} / \mathrm{L}$. Maximum concentrations of nickel were $2.10 \mu \mathrm{g} / \mathrm{L}$ in 2010 and $3.20 \mu \mathrm{g} / \mathrm{L}$ in 2011 which were much lower than MPC standard, $10 \mu \mathrm{g} / \mathrm{L}$. Cadmium and manganese were present in all analysed samples in 2010 and 2011 with maximum cadmium and manganese content of $0.60 \mu \mathrm{g} / \mathrm{L}$ (MPC, $5 \mu \mathrm{g} / \mathrm{L}$ ) and $4.50 \mu \mathrm{g} / \mathrm{L}$ (MPC, 10 $\mu \mathrm{g} / \mathrm{L}$ ), respectively. Fluorides were found with concentrations up to $0.370 \mathrm{mg} / \mathrm{L}$ in $50 \%$ of the samples in 2010 and not detected in 2011. River water was characterized by low salt content, mainly calcium hydrocarbonate, within the range of $136-218 \mathrm{mg} / \mathrm{L}$ in 2010 , and from 163 to $222 \mathrm{mg} / \mathrm{L}$ in 2011. Other water quality indicators, such as chromium (6+), vanadium, mercury, arsenic, beryllium and volatile phenols were not found in water samples collected in 2010 and 2011.

3.5.2 Phosphorus and nitrogen

Phosphates and silicon from biogenic compounds group were detected in water within regulatory levels. Some growth of phosphate up to $0.157 \mathrm{mg} / \mathrm{L}$ was recorded in May 2010 during the flood season, they were not found in June and August 2011.

Since there is no negative impact from those tributaries in this section flowing into the river downstream, the pollution level is considered as acceptable.

\subsection{Hydrochemical and toxicological indicators of the Irtysh River in Pavlodar city}

The observation point at Pavlodar, $0.5 \mathrm{~km}$ downstream the Gorvodokanal discharge, is the last monitoring point on Irtysh River before the river flows out of Kazakhstan.

\subsubsection{Mineral contents}

Exceedance of total iron was only observed in May 2010 (2.6MPC) and not found in 50\% samples. The concentration of copper varied from 0.8 to $4.8 \mu \mathrm{g} / \mathrm{L}$ (up to $4.8 \mathrm{MPC}$ ), and had the average value of 2.0MPC. The concentration of nickel and manganese, 2.5 and $3.2 \mu \mathrm{g} / \mathrm{L}$ respectively, were constantly lower than the MPC standard level of $10 \mu \mathrm{g} / \mathrm{L}$. Zinc was detected at $1.00 \mu \mathrm{g} / \mathrm{L}$ in $25 \%$ of samples. Cadmium content was low in the range of $0.0-0.40 \mu \mathrm{g} / \mathrm{L}$ with an annual average value of $0.18 \mu \mathrm{g} / \mathrm{L}$ which was lower than the standard MPC level of $5 \mu \mathrm{g} / \mathrm{L}$. Other elements such as chromium (6+), vanadium, mercury, arsenic and volatile phenols were not detected in the river water. Salt water content remained stable from upper stream within the range of $178-216 \mathrm{mg} / \mathrm{L}$.

\subsubsection{Phosphorus and nitrogen}

The excess of nitrite nitrogen content was observed only in December with the concentration of $0.034 \mathrm{mg} / \mathrm{L}$ which was lower than the MPC standard level of $0.02 \mathrm{mg} / \mathrm{L}$ and was only found in $25 \%$ of the samples. Phosphates and silicon content were recorded below the regulatory limits.

\subsubsection{Organic content}

Dichromate oxidizability still remained at low level from 5.0 to $9.4 \mathrm{mg} \mathrm{O}_{2} / \mathrm{L}$. The average $\mathrm{BOD}_{5}$ was $1.21 \mathrm{mg} \mathrm{O} 2 / \mathrm{L}$. Average concentration of petroleum products amounted to $0.022-0.03 \mathrm{mg} / \mathrm{L}$ and lower than the MPC standard level of $0.05 \mathrm{mg} / \mathrm{L}$.

Therefore, the Irtysh River in Pavlodar city section was not characterized as significantly polluted. But as previous analyzed, the heavy metal iron could not be purified by the nature processes. The possible reason of reducing concentration might be due to dilution or adsorption by the sludge of the river bed. This river section is considered as having capable ability of selfpurification from the evolution of total phosphorus and total nitrogen value. 


\subsection{Toxicity assessment of the Irtysh River and its tributaries by biotesting method}

Biotesting method is a useful assessment for the water toxicity analysis. Daphnia and other organisms are commonly used as the test object (Bubnov et al., 2007). However, this method cannot detect which chemical compounds have an impact on water toxicity and causing loss of the test objects. Possible causes of acute toxicity in water are shown in Table 2, which represent the sampling of recorded cases of high water toxicity of monthly tests carried out by East Kazakhstan Hydrometeorology Center and our additions on the test objects loss.

As can be seen from the table below, the tributaries of the Irtysh River are particularly polluted (Table 2). There are some toxic metals with high concentration in the river water, such as copper, zinc or manganese. This pollution factor is due to sewage and other waste of mining and metallurgical industry. Basically, these toxicants create a high level of toxicity in these water streams, which cause the loss of test objects, in most cases up to $100 \%$.

Table 2 Results of biotesting experiments and causes for acute water toxicity in 2011

\begin{tabular}{|c|c|c|c|c|c|c|c|c|c|c|}
\hline \multirow{2}{*}{ Hydro-post (associating) } & \multirow{2}{*}{ Month } & \multirow{2}{*}{$\begin{array}{l}\text { Survival } \\
\text { rate } \\
(\%)\end{array}$} & \multicolumn{2}{|c|}{$\begin{array}{c}\text { Zinc } \\
(\mu \mathrm{g} / \mathrm{L})\end{array}$} & \multicolumn{2}{|c|}{$\begin{array}{l}\text { Manganese } \\
(\mu \mathrm{g} / \mathrm{L})\end{array}$} & \multicolumn{2}{|c|}{$\begin{array}{l}\text { Copper } \\
(\mu \mathrm{g} / \mathrm{L})\end{array}$} & \multicolumn{2}{|c|}{$\begin{array}{c}\text { Ammonium } \\
\text { nitrogen }(\mathrm{mg} / \mathrm{L})\end{array}$} \\
\hline & & & Actual & MPC & Actual & MPC & Actual & MPC & Actual & MPC \\
\hline \multirow{2}{*}{$\begin{array}{l}0.1 \mathrm{~km} \text { downstream the zinc factory } \\
\text { discharge, Ridder city, Tihaya River }\end{array}$} & January & 46.7 & 178 & 17.8 & 21 & 2.1 & - & - & - & - \\
\hline & August & 0.0 & 441 & 44.1 & 77 & 7.7 & - & - & - & - \\
\hline $\begin{array}{l}50 \mathrm{~m} \text { upstream the mine water } \\
\text { discharge of Tishinsky mine, Ulba } \\
\text { River }\end{array}$ & January & 6.6 & 254 & 25.4 & 18 & 1.8 & - & - & - & - \\
\hline \multirow{2}{*}{$\begin{array}{l}4.8 \mathrm{~km} \text { downstream the mine waters } \\
\text { discharge of Tishinsky mine, Ulba } \\
\text { River }\end{array}$} & January & 0.0 & 355 & 35.5 & 27 & 2.7 & - & - & - & - \\
\hline & February & 0.0 & 485 & 48.5 & 38 & 3.8 & 7.6 & 7.6 & - & - \\
\hline \multirow{2}{*}{$\begin{array}{l}1.45 \mathrm{~km} \text { upstream the Ulba River } \\
\text { mouth; at the highway bridge, Ust- } \\
\text { Kamenogorsk city, Ulba River }\end{array}$} & January & 6.6 & 106 & 10.6 & - & - & - & - & - & - \\
\hline & January & 0.0 & 106 & 10.6 & - & - & - & - & - & - \\
\hline \multirow{4}{*}{$\begin{array}{l}0.5 \mathrm{~km} \text { downstream Berezovsky mine; } \\
\text { at the highway bridge, Predgornoye } \\
\text { village, Krasnoyarka River }\end{array}$} & January & 0.0 & 2,148 & 215 & 196 & 19.6 & 51 & 51 & - & - \\
\hline & February & 3.3 & 1,827 & 183 & 65 & 6.5 & 2.4 & 2.4 & - & - \\
\hline & July & 0.0 & 1,558 & 156 & 125 & 12.5 & 3.5 & 3.5 & - & - \\
\hline & August & 3.3 & 1,452 & 145.2 & 133 & 13.3 & 4.8 & 4.8 & - & - \\
\hline $\begin{array}{l}5.5 \mathrm{~km} \text { upstream the household fecal } \\
\text { water discharge of Belousovka village, } \\
\text { Belousovka village, Glubochanka River }\end{array}$ & July & 20.0 & - & - & 10 & 1 & - & - & 1.59 & 4 \\
\hline $\begin{array}{l}1.5 \mathrm{~km} \text { upstream the household waste } \\
\text { water discharge of Irtyshsky mine, } \\
\text { Predgornoye village, Krasnoyarka } \\
\text { River }\end{array}$ & July & 20.0 & - & - & 16 & 1.6 & 2.3 & 2.3 & - & - \\
\hline $\begin{array}{l}\text { within the precincts of a town; } 0.6 \mathrm{~km} \\
\text { upstream the Breksa River mouth }\end{array}$ & August & 0.0 & 441 & 44.1 & 68 & 6.8 & 6.5 & 6.5 & - & - \\
\hline
\end{tabular}

\section{Conclusions}

According to the results of water quality surveys of the Irtysh River with respect to the maximum permissible concentration, some conclusions can be drawn based on the data analysis.

From the basin aspect, the transboundary runoff of the Irtysh River is not characterized as severe pollution by the common examine of concentration. The general water quality parameters are considered as acceptable. Exceedance of copper and other irons for MPC standard level was observed in certain periods and certain river sections due to the flood but has not yet cause the noticeable deterioration of the river water quality. The possible reason may be that the mineral dust from the surrounding mining activities were washed out and transported into river network, or the copper deposition in the sediment was perturbed by high flow motions.

From spatial aspect, upper stream of Irtysh River shows low pollution level and no impact from its tributaries. The pollution level of the middle-stream after Ust-Kamenogorsk has an increasing trend due to exceedance of the MPC for certain heavy metals (zinc, copper and manganese) and compounds of nitrogen group. The main reason is that the tributary, Krasnoyarka River, is heavily 
contaminated by the mining and industrial emissions. Such contamination is a powerful factor which impact toxicological status of not only the Krasnoyarka River but also the Irtysh River. The downstream shows high self-purification capacity so that the water qualities after Semey/Semipalatinsk and Pavlodar are not significantly polluted.

However, the biotesting results present some interesting features which might be contrary with MPC analysis. The best survival rate of the test objects in the samples does not exceed $46.7 \%$, furthermore and 7 samples lost all the test objects. This situation indicates that a high degree of toxicity has severe impact on the biological processes in the tributaries of the Irtysh River.

The differences between MPC and biotesting methods are associated with different approaches to the definition of water pollution. In this study, the two approaches show the contrary situation. MPC approach is defined only for a single item, i.e. laboratory tests were carried out for a single pollutant. The impact of pollutant combination on living organisms has not been tested in the laboratory. The joint impact of elements and their compounds have not been surveyed thoroughly. Regarding to this reason, the assessment of water toxicity by using the biotesting method is a more representative way to evaluate the water quality impacts to the living creatures. Although the biotesting method cannot determine which kind of the pollutant causes the death of plankton. By combing the chemical assessment with the biotesting method, it will provide a more detailed understanding for the dynamic regime of water quality.

\section{Acknowledgements}

This work was partially supported by International Science \& Technology Cooperation Program of China (2010DFA92720-04).

\section{References}

Alekin O A. 1970. Fundamentals of hydrochemistry. Leningrad: Gidrometeoizdat, 121-374. (in Russian)

Amirgaliyev N A. 1998. Artificial water bodies of Northern and Central Kazakhstan: hydrochemistry and water quality. Almaty: Bastau, 187-191. (in Russian)

Boyd C E, Tucker C S. 2012. Pond Aquaculture Water Quality Management. Dordrecht: Kluwer Academic Publishers, 1-7.

Bubnov A G, Buymova S A, Gushchin A A, et al. 2007. Analysis of Biotest-Integral Method of Assessment for assessing the Quality of the Environment. Ivanovo: Ivanov State University of Chemistry and Technology, 102-112. (in Russian)

Burlibayev M Z, Murtazin E Z, Bazarbaev S K, et al. 2002. Modern State of Pollution of Main Waterways of Kazakhstan by Heavy Metal Ions. Almaty: Kaganat, 256. (in Russian)

Burlibayev M Z, Murtazin E Z, Bazarbaev S K, et al. 2003. Nutrients in Main Waterways of Kazakhstan. Almaty: Kaganat, 723. (in Russian)

Burlibayev M Z, Murtazin Y Z, Tursunov E A. 2006. Rivers' hydro-chemical regime. In: Iskakova N A, Medeu A R. Republic of Kazakhstan, Vol. I: Natural Conditions and Resources. Almaty: Ministry for Environmental Protection, 257-263. (in Russian)

Burlibayev M Z, Amirgaliyev N. 2012. Water Pollution Comprehensive Index of Surface Waters by Hydro Chemical Parameters. Almaty: Astana, 81. (in Russian)

Burlibayev M Z, Kutz S I, Faschevsky B V, et al. 2014. Flooding of the Irtysh River Floodplain-The Main Factor of Sustainable Development of the River Ecosystem. Almaty: Kaganat, 396. (in Russian)

Edet A, Ukpong A, Nganje T. 2013. Hydrochemical studies of Cross River Basin (southeastern Nigeria) river systems using cross plots, statistics and water quality index. Environmental Earth Sciences, 70(7): 3043-3056.

Evgeniev M I. 1999. Test methods and ecology. Soros Educational Journal, 11: 29-34. (in Russian)

Hem J D. 1985. Study and interpretation of the chemical characteristics of natural water ( $3^{\text {rd }}$ ed.). US Geological Survey WaterSupply, Charlottesville: University of Virginia, 2254.

INGEO. 2012. Water Resources of Kazakhstan: Assessment, Prediction, and Management. In: INGEO. Natural Water of Kazakhstan: Resources, Regime, Quality, and Prediction (Vol. II). Almaty: Institute of Geography, Ministry of Education and Science, Kazakhstan, 330. (in Russian)

Juahir H, Zain S M, Yusoff M K, et al. 2011. Spatial water quality assessment of Langat River Basin (Malaysia) using environmetric techniques. Environmental Monitoring and Assessment, 173(1-4): 625-641.

Khan S, Shahnaz M, Jehan N, et al. 2013. Drinking water quality and human health risk in Charsadda district, Pakistan. Journal 
of Cleaner Production, 60: 93-101.

Olmanson L G, Brezonik P L, Bauer M E. 2013. Airborne hyperspectral remote sensing to assess spatial distribution of water quality characteristics in large rivers: the Mississippi River and its tributaries in Minnesota. Remote Sensing of Environment, 130: 254-265.

Osibanjo O, Daso A P, Gbadebo A M. 2011. The impact of industries on surface water quality of River Ona and River Alaro in Oluyole Industrial Estate, Ibadan, Nigeria. African Journal of Biotechnology, 10(4): 696-702.

Ministry of Ecology and Bioresources, Kazakhstan. 1994. Rules of surface water protection of the Republic of Kazakhstan. The Ministry of Ecology and Bioresources, Protocol No. 13, 17. (in Russian)

Ministry of Healthcare and Social Development (MZSR), Kazakhstan. 1991a. Collection of sanitary standards and methods of control of hazardous substances in the environment. Moscow: Ministry of Healthcare and Social Development, the Republic of Kazakhstan, 370. (in Russian)

MZSR. 1991b. Standards of water quality of water bodies of fisheries significance, including the standards of maximum permissible concentrations of harmful substances in water of water bodies of fisheries significance. Moscow: Ministry of Healthcare and Social Development, the Republic of Kazakhstan, 191. (in Russian)

Republican State Enterprise (RSE). State Water Cadastre. 2007. Annual data on surface water quality. Issue 1, the Irtysh river basin. Serial publication. Almaty: Kazgidromet, 220. (in Russian)

RSE, State Water Cadastre. 2008. Annual data on surface water quality. Issue 1 - the Irtysh river basin. Serial publication. Almaty: RSE “Kazgidromet”, 228. (in Russian)

RSE, State Water Cadastre. 2009. Annual data on surface water quality. Issue 1 - the Irtysh river basin. Serial publication. Almaty: RSE “Kazgidromet”, 239. (in Russian)

RSE, State Water Cadastre. 2010. Annual data on surface water quality. Issue 1 - the Irtysh river basin. Serial publication. Almaty: RSE “Kazgidromet”, 235. (in Russian)

RSE, State Water Cadastre. 2011. Annual data on surface water quality. Issue 1 - the Irtysh river basin. Serial publication. Almaty: RSE "Kazgidromet”, 231. (in Russian)

Shah Z A, Umar R. 2015. Stable isotopic and hydrochemical studies in a part of central Ganga basin. Journal of the Geological Society of India, 85(6): 706-716.

Shrestha S, Kazama F. 2007. Assessment of surface water quality using multivariate statistical techniques: A case study of the Fuji river basin, Japan. Environmental Modelling \& Software, 22(4): 464-475.

Stumm W, Morgan J J. 2012. Aquatic Chemistry: Chemical Equilibria and Rates in Natural Waters. Vol. 126, New York: John Wiley \& Sons, 1040 .

Sun J B, Chen Y, Zhang Z, et al. 2015. The spatio-temporal variations of surface water quality in China during the "Eleventh Five-Year Plan”. Environmental Monitoring and Assessment, 187: 64.

Turner R E, Rabalais N N. 1991. Changes in Mississippi River water quality this century: Implications for coastal food webs. BioScience, 41(3): 140-147.

UNDP. 2004. Water Resources of Kazakhstan in the New Millennium. Almaty: UNDP, 124,132.

Varol M, Gökot B, Bekleyen A, et al. 2012. Spatial and temporal variations in surface water quality of the dam reservoirs in the Tigris River basin, Turkey. Catena, 92: 11-21.

Vendrov S L, Kalinin G P. 1960. Surface-water resources of the USSR: their utilization and study. Soviet Geography, 1(6): 35-49.

Zenin A A, Belousova N V. 1988. Dictionary of hydro-chemistry terms. Leningrad: Gidrometioizdat, 238. 